\title{
PENINGKATAN PEMAHAMAN BENTUK GEOMETRI ANAK USIA 5-6 TAHUN MELALUI KEGIATAN SENI DAN KERAJINAN TANGAN (ART AND CRAFT) \\ Fitri Ramadhini $^{1,}$ Nur Imam Mahdi ${ }^{2}$ \\ ${ }^{1,2}$ Institut Agama Islam Negeri Padangsidimpuan \\ E-mail: f.ramadhini@iain-padangsidimpuan.ac.id
}

\begin{abstract}
ABSTRAK
Penelitian ini bertujuan untuk menjelaskan proses dan hasil dengan menggunakan kegiatan Seni dan Kerajinan Tangan (Art And Craft) dalam meningkatkan pemahaman bentuk geometri anak usia 5-6 tahun di PAUD Al-Ikhlas Salemba Tengah, Jakarta Pusat pada tahun 2015. Metode penelitian yang digunakan adalah model penelitian tindakan Kemmis \& Taggart yang terdiri dari: (a) perencanaan, (b) tindakan dan observasi, dan (c) refleksi. Instrumen yang digunakan dalam penelitian ini adalah observasi, wawancara, dan dokumentasi. Skor data dari pemahaman bentuk geometri anak dianalisis dengan menggunakan pendekatan kuantitatif dan kualitatif. Hasilnya menunjukkan bahwa pemahaman bentuk geometri anak telah meningkat. Bila pre test pemahaman geometri anak secara signifikan $46 \%$ dan pada siklus I menjadi $61 \%$. Skor pada siklus II meningkat sekitar $12,19 \%$ dan mendapat skor $86 \%$. Kesimpulan dari penelitian ini adalah (1) proses penggunaan kegiatan art and craft dapat meningkatkan pemahaman bentuk geometri anak pada PAUD Al-Ikhlas Salemba Tengah, Jakarta Pusat 2015, (2) pemahaman bentuk geometri anak di PAUD Al-Ikhlas Salemba Tengah, Jakarta Pusat pada tahun 2015 meningkat dari pra siklus ke siklus pertama dan siklus kedua.
\end{abstract}

Kata Kunci: Geometri; Pemahaman; Art and Craft; Taman Kanak-kanak

\section{PENDAHULUAN}

Matematika merupakan salah satu cabang dari ilmu pengetahuan dan disiplin ilmu yang sangat bermanfaat bagi kehidupan, baik berdasarkan materi maupun kegunaannya. Matematika merupakan ilmu pengetahuan yang memiliki peran penting dalam kehidupan manusia, karena setiap aktivitas kehidupan tidak lepas dari konsep matematika. Salah satu apek yang perlu dikembangkan pada anak usia dini adalah kemampuan matematika. Dengan memahami konsep matematika diharapkan anak dapat meningkatkan kemampuan berpikir logis anak.

Kemampuan pemahaman matematis adalah salah satu tujuan penting dalam pembelajaran matematika. Hal ini menunjukkan bahwa materi-materi yang disampaikan kepada anak tidak hanya sekedar menghafal tetapi dengan memahami konsep. Dengan penguasaan konsep maka akan memudahkan anak dalam mempelajari matematika. Salah satu komponen dari matematika yang sering ditemui di sekitar adalah geometri. Dalam mempelajari gometri penting sekali memahami konsep-konsep yang terkandung di dalamnya. Geometri merupakan dasar dalam matematika dan pembangunan. Banyak konsep matematika yang dapat ditunjukkan dan diterangkan dengan representasi geometris. 
Geometri adalah salah satu bidang dalam matematika yang mempelajari tentang bentuk, ukuran, ruang, posisi, dan arah. Dunia ini dibangun dengan konsep geometri. Hampir dalam semua bidang kehidupan seperti dalam bidang seni, arsitektur, robotika, astronomi, dan banyak bidang lainnya menggunakan dasar pemahaman geometri. Setiap aktivitas sehari-hari entah disadari atau tidak, menggunakan konsep geometri. Geometri merupakan salah satu komponen dari matematika yang sering ditemui di lingkungan sekitar, tidak terkecuali di lingkungan anak usia dini.

Pengenalan konsep bentuk geometri secara spontan dapat dilihat ketika anak usia dini sedang bermain. Sewaktu bermain balok misalnya anak mengenal konsep geometri. Saat menggambar, anak menggunakan bentuk geometri dasar seperti lingkaran, persegi, persegi panjang, dan segitiga. Konsep geometri tidak luput dari kehidupan sehari-hari anak usia dini seperti lantai berbentuk persegi, jam berbentuk lingkaran, dan atap rumah berbentuk segitiga. Hal inilah yang menunjukkan bahwa pentingnya peran geometri dalam kehidupan manusia tidak lepas dari pemahaman bentuk geometri. Ironisnya berdasarkan survei yang dilakukan oleh Program for International Student Assessment (PISA) di bawah Organization Economic Cooperation and Development (OECD) menyatakan bahwa kemampuan matematika siswa-siswi di Indonesia menduduki peringkat 64 dari 65 negara alias kedua dari bawah dengan skor 375. Kurang dari $1 \%$ siswa Indonesia yang memiliki kemampuan bagus di bidang matematika. Fakta ini diperparah oleh data yang dijabarkan oleh UNESCO, yaitu mutu pendidikan matematika di Indonesia berada pada peringkat 34 dari 38 negara yang diamati. ${ }^{1}$ Data lain yang menunjukkan rendahnya prestasi matematika siswa Indonesia dapat dilihat dari hasil survei Pusat Statistik Internasional untuk Pendidikan (National Center for Education in Statistics, 2003) terhadap 41 negara dalam pembelajaran matematika, dimana Indonesia mendapatkan peringkat ke 39 di bawah Thailand dan Uruguay. ${ }^{2}$ Berdasarkan hal tersebut maka pemahaman anak mengenai konsep matematika khususnya bentuk geometri perlu diperkenalkan melalui stimulasi sejak anak berusia dini, karena masa usia dini adalah masa yang tepat dalam mengenalkan konsep-konsep matematika terutama geometri.

\footnotetext{
${ }^{1}$ Nograhany Widhi K, Ini Peringkat Kemampuan Matematika Siswa di Dunia, Indonesia Nomor Berapa?, http://news.detik.com/read/2013/12/04/144949/2432402/10/ini-peringkat-kemampuan-matematika-siswa-di-duniaindonesia-nomor-berapa diakses pada tanggal 19 Juni 2014

${ }^{2}$ Satria, Mutu Pendidikan di Indonesia Masih Rendah, http://ugm.ac.id/id/post/page?id=4467 diakses pada tanggal 19 Juni 2014
} 
Berdasarkan hasil observasi yang dilakukan di PAUD Al-Ikhlas Jalan Salemba Tengah RT.05 RW.04 Jakarta Pusat, mengenai pembelajaran geometri. Maka diperoleh data dari hasil kegiatan pembelajaran di kelompok B yang berada pada rentang usia 5-6 tahun masih terdapat 8 orang anak dari 15 siswa di kelompok B masih mengalami kesulitan dalam mengenal bentuk geometri. Sebagai contoh anak belum mampu membedakan bentuk geometri persegi dengan persegi panjang dan segitiga, bahkan beberapa anak menyebutkan lingkaran sebagai bulat.

Pemahaman bentuk geometri yang diharapkan muncul pada anak usia 5-6 tahun adalah anak mampu mengenali bentuk geometri beserta namanya, membandingkan bentuk geometri, mengengenali ciri-ciri bentuk geometri seperti lingkaran, persegi, persegi panjang, dan segitiga. Dasar pemahaman ini perlu dikembangkan agar anak mampu menciptakan gambaran mental dari bentuk geometris dan mengembangkan konsep pemahaman ruang, mengenali dan dapat menunjukkan bentuk geometri dari perspektif yang berbeda, dan mengenal bentuk dan struktur geometris dalam lingkungan sekitar anak.

Berdasarkan hal tersebut, peneliti tertarik untuk meneliti tentang bagaimana penggunaan kegiatan art and craft dapat meningkatkan pemahaman bentuk geometri sehingga kemampuan anak dalam memahami bentuk geometri dapat meningkat. Melalui penelitian tindakan ini diharapkan dapat memberikan alternatif solusi berupa kontribusi positif pada pihak sekolah.

Geometri merupakan salah satu cabang dalam ilmu matematika yang perlu dipelajari sedini mungkin, karena banyaknya konsep-konsep yang termuat di dalamnya. Geometri pertama kali diperkenalkan oleh Thales (624-547 SM). Geometri berasal dari bahasa Yunani yaitu geo yang artinya bumi dan metro yang artinya mengukur. ${ }^{3}$ Geometri secara harfiah dapat dideskripsikan sebagai ilmu ukur tentang bumi, yakni ilmu yang mempelajari hubungan di dalam ruang.

Sejalan dengan pendapat tersebut Jannah mengemukakan bahwa geometri adalah ilmu yang membahas bentuk, bidang, dan ruang suatu benda (terutama luas dan volume). ${ }^{4}$ Berdasarkan pendapat tersebut maka geometri dapat dideskripsikan sebagai ilmu pengetahuan praktis yang membahas bentuk, bidang, dan ruang yang terdapat disekitar lingkungan fisik manusia.

\footnotetext{
${ }^{3}$ Nusrotul Bariyah, http://nusrotulbariyah.wordpress.com/2010/01/16/geometri/ diakses pada tanggal 24 Maret 2014.

${ }^{4}$ Raodatul Jannah. Membuat Anak Cinta Matematika dan Eksak lainnya (Jogjakarta: DIVA Press, 2011 ), hlm. 32.
} 
Hal ini dipertegas kembali oleh Jackman yang mengemukakan bahwa geometri yaitu "area of mathematics that involve shape, size, space, position, direction, and movement, and describe and classifies world we live in". 5 Berdasarkan pendapat tersebut maka dapat diartikan bahwa geometri merupakan bidang matematika yang melibatkan bentuk, ukuran, ruang, posisi, arah, dan gerak, dan menjelaskan serta mengklasifikasikan dunia tempat manusia hidup. Pengertian tersebut menyiratkan bahwa geometri dapat menjelaskan dan mendeskripsikan dunia dengan ruang, posisi, arah, dan gerak karena setiap unsur tersebut geometri ada disetiap elemen kehidupan.

Pendapat tersebut sejalan dengan Freudenthal dalam NCTM yang mengemukakan "geometry, the study of shapes in space and spatial relationships". 6 Berdasarkan pendapat tersebut dapat dijelaskan bahwa geometri adalah studi mengenai bentuk dalam ruang dan hubungan spasial. Kesadaran dalam hubungan spasial sangat penting dikembangkan sebelum anak mulai berpikir secara matematis menggunakan konsep geometri.

Berdasarkan uraian pendapat dari beberapa tokoh mengenai pengertian geometri, maka dapat dideskripsikan bahwa geometri adalah salah satu cabang dari ilmu matematika yang membahas tentang sifat-sifat dari garis, sudut, bidang, dan ruang yang ada dalam kehidupan, karena dunia ini dibangun dengan konsep geometri. Geometri merupakan penyajian abstraksi dari pengalaman visual dan spasial dari garis, sudut, bidang, dan ruang.

\section{Pemahaman Bentuk Geometri Anak Usia Dini}

Anak usia dini mulai memahami konsep geometri melalui lingkungan fisik di sekitarnya, anak mengeksplorasi bentuk geometri dan penalaran ruang saat bermain. Dalam memahami bentuk geometri anak harus terlibat dalam kegiatan secara langsung dan menggunakan media yang variatif. Hal ini sejalan dengan pendapat Copple dan Brede Kamp yang mengemukakan bahwa "to learn about shapes, children need to play with them through games, toys, art activities, fingerplays, songs, poems, and stories". 7 Berdasarkan pendapat tersebut maka dapat diartikan bahwa untuk belajar mengenai bentuk, anak perlu bermain melalui permainan, mainan, kegiatan seni, permainan jari, lagu, puisi dan cerita. Hal ini menunjukkan bahwa melalui

\footnotetext{
${ }^{5}$ Hilda L. Jackman. Early Education Curriculum (United State of Amerika: Delmar, 2009), hlm. 161.

${ }^{6}$ The National Council of Teachers of Mathematics, Inc. Mathematics for The Young Child (United State of America: Library of Congress Cataloging-in-Publication Data, 1990), hlm. 203.

${ }^{7}$ Claudia E"liaison dan Ioan Jenkins. A Practical Guide to Early Childhood Education Curriculum (United State of Amaerica: Pearson, 2012), hlm. 313.
} 
kegiatan bermain yang menyenangkan anak mampu memahami bentuk-bentuk geometri secara alamiah.

Membangun konsep pemahaman bentuk geometri pada anak usia dini dapat dimulai dengan mengenalkan, menunjukkan, menyebutkan serta mengumpulkan benda-benda di sekitar anak berdasarkan bentuk geometri. Hal ini sejalan dengan standar yang dikemukakan oleh National Council of Teachers of Mathematics (NCTM) mengenai standar pemahaman geometri anak usia dini yang menyatakan:

“in prekindergarten through grade 2 all students should recognize, name, build, draw, compare, and sort two- and three-dimensional shapes, describe attributes and parts of two- and three-dimensional shapes, investigate and predict the results of putting together and taking apart two- and three-dimensional shapes". 8

Berdasarkan pernyataan tersebut dapat diartikan bahwa anak usia pra sekolah-kelas 2 harus mampu mengenali, menamai, membangun, menggambar, membandingkan dan memisahkan bentuk geometri dua dan tiga dimensi. Menjelaskan ciri-ciri dan bagian-bagian geometri dua dan tiga dimensi. Menyelidiki dan memperkirakan hasil dari penyatuan dan pemisahan bentuk geometri dua dan tiga dimensi. Guna mencapai standar yang telah ditetapkan tentunya diperlukan media yang dapat mengantarkan anak pada pemahaman bentuk geometri dan metode disesuaikan dengan karakteristik anak, tahapan usia anak dan juga dengan tahapan perkembangan anak serta melibatkan anak secara langsung dalam memahami konsep bentuk geometri.

Hal tersebut sejalan dengan pendapat Clements, Wilson dan Sarama yang menyatakan bahwa membangun konsep geometri pada anak dimulai dengan mengidentifikasi bentuk-bentuk dan menyelidiki bangunan dan memisahkan gambar-gambar biasa seperti segi empat, lingkaran, segitiga. ${ }^{9}$ Berdasarkan hal tersebut maka dapat dijelaskan bahwa anak usia dini memulai konsep geometri dari konsep indentifikasi, menyelidiki, dan memisahkan bentuk-bentuk geometri dasar seperti lingkaran, segi empat dan segitiga.

Konsep pertama yang perlu diajarkan pada anak usia dini sebagai dasar untuk memahami bentuk geometri adalah kesadaran ruang/spasial. Hal ini sejalan dengan pendapat Smith yang

\footnotetext{
${ }^{8}$ Tipps Johnson Kennedy. Guiding Children"s Learning of Mathematics (Unites State of America: Cengage Learning, 2011), hlm. 418.

${ }^{9}$ Carol Seefeldt dan Barbara A.Wasik. Menyiapkan Anak Usia Tiga, Empat, dan Lima Masuk Sekolah Edisi Bahasa Indonesia (Jakarta: Indeks, 2008), hlm. 398.
} 
menyatakan bahwa "young children begin their study of geometry with the topic of topology, a special kind of geometry that investigates these kinds relationships". ${ }^{10}$ Berdasarkan pernyataan tersebut maka dapat diartikan bahwa anak usia dini mulai mempelajari geometri dengan topik topologi, yaitu bagian khusus dari geometri yang menyelidiki tentang hubungan-hubungan. Hubungan yang dimaksudkan adalah hubungan letak atau ruang.

Hal tersebut dipertegas kembali oleh Smith bahwa yang dimaksud dengan topologi adalah "study of the relationships between objects, place, or events". "11 Berdasarkan pendapat tersebut maka dapat diartikan bahwa topologi adalah adalah studi tentang hubungan antara objek, tempat, atau kejadian. Berdasarkan pendapat tersebut maka dapat diartikan geometri topologi menjelaskan bagaimana benda-benda di dalam ruang berhubungan satu dengan lainnya. Berdasarkan hal tersebut maka anak usia dini memulai pemahaman tentang bentuk geometri diawali dengan mengembangkan pemahaman ruang antar objek, tempat, dan benda dalam suatu kejadian.

Dalam memahami geometri topologi terdapat empat konsep yang harus dipahami sebagai dasar pemahaman bentuk geometri, empat konsep tersebut yaitu:

"proximity, separation, order, and enclosure, form the foundation for preschool/kindergarten experiences in geometry. Proximity refers to question about position, directions, and distance. Separation refers to the ability to see a whole objects as composed of individual parts or pieces. Order refers to the sequence of object or events. Enclosure refers to being surrounded or boxes in by surrounding objects". ${ }^{12}$

Berdasarkan kutipan tersebut maka dapat diartikan bahwa empat konsep yang membentuk dasar untuk pengalaman geometri di TK adalah proximity, separation, order, and enclosure. Proximity mengacu pada pertanyaan tentang posisi, arah, dan jarak seperti di dekat, jauh, atas, bawah, besar, kecil, di sini, di sana, masuk dan keluar. Separation mengacu pada kemampuan untuk melihat keseluruhan benda yang terdiri dari bagian-bagian seperti "roti ini dapat dibagi menjadi dua, di dalam kelas terdapat anak laki-laki dan perempuan, dan lainnya". Order mengacu pada urutan objek atau kejadian, kosakata yang dapat digunakan untuk

\footnotetext{
${ }^{10}$ Susan Sperry Smith. Early Childhood Mathematics Fourth Edition (United State of America: Pearson, 2009), hlm 192.

${ }^{11}$ Smith. Early Childhood Mathematics Fourth Edition (United State of America: Pearson, 2009), hlm 192.

${ }^{12}$ Smith. Early Childhood Mathematics Fourth Edition (United State of America: Pearson, 2009), hlm. 193.
} 
membantu dalam memahami konsep ini adalah pertama, belakang, tengah, depan dan seterusnya. Enclosure mengacu pada benda-benda yang ada di sekitar, seperti benda yang berada di dalam, di luar, dan di atas.

Berdasarkan penjelasan di atas, ditekankan kembali oleh Piaget dan Inhaler dalam Aubrey yang menyatakan bahwa "children deal first with ,topological" aspects of shape between 2 and 4 years; distinguish, "projective" aspects, such as curved or straight-sidedness at 4 to 6 years; and finally explore „Euclidean" notions of length, angle, size and area, to discrimate among complex shapes, at 6 to 8 years". ${ }^{13}$ Berdasarkan pernyataan tersebut maka dapat diartikan bahwa anak usia dini mulai berinteraksi dengan aspek dari bentuk, ,topologie antara usia 2 dan 4 tahun, anak mampu membedakan aspek ,,proyektif ${ }^{e e}$, seperti melengkung atau sisi pada usia 4 sampai 6 tahun, dan akhirnya mengeksplorasi gagasan „Euclidean“e seperti panjang, sudut, ukuran dan daerah, untuk membedakan bentuk-bentuk yang kompleks pada usia 6 sampai 8 tahun.

Berdasarkan uraian pendapat dari beberapa tokoh mengenai pemahaman bentuk geometri anak usia dini maka dapat dideskripsikan bahwa pemahaman bentuk geometri pada anak usia 5-6 tahun diawali dengan mengembangkan kesadaran ruang/spasial selanjutnya anak mulai dikenalkan dengan berbagai bentuk geometri dasar yang berbentuk bangun datar maupun banggun ruang, serta mengenal nama dan ciri dari berbagai bentuk geometri dasar. Bentuk geometri dasar yang dapat diajarkan pada anak usia dini adalah bentuk geometri dasar seperti lingkaran, segitiga, persegi, dan persegi panjang. Berdasarkan hal tersebut maka pemahaman bentuk geometri pada anak usia dini dapat diartikan sebagai kemampuan anak dalam menangkap makna dalam pembelajaran bentuk geometri yang ditujukan dengan beberapa kemampuan yang meliputi kemampuan menafsirkan, memberikan contoh yang berkaitan dengan bentuk geometri, mengklasifikasikan, merangkum, menyimpulkan, dan memberikan penjelasan mengenai bentuk geometri.

\section{METODE PENELITIAN}

Metode penelitian yang digunakan dalam penelitian ini adalah metode action research atau penelitian tindakan dengan model penelitian yang dikembangkan oleh Kemmis dan Taggart, dan dilaksanakan melalui dua siklus yang meliputi perencanaan, tindakan dan observasi, serta refleksi.

${ }^{13}$ Carol Aubrey. Mathematics Teaching in the early Years (Britain: The Falmer Press, 1997), hlm. 66. 
Teknik pengumpulan data yang dilakukan dalam penelitian ini adalah observasi, wawancara, dan dokumentasi. Analisis data dilakukan dengan pendekatan kualitatif dan kuantitatif. Data berupa observasi yang terkandung dalam catatan lapangan yang akan dianalisis dengan menggunakan metode, Miles dan Huberman dalam Arikunto (2006) dengan komponen reduksi data, penyajian data, dan kesimpulan. Analisis data kuantitatif menggunakan analisis statistik deskriptif, yaitu analisis data dengan observasi menggambarkan pemahaman konsep jumlah anak dalam bentuk tabel data dan grafik atau diagram.

\section{HASIL PENELITIAN}

Hasil penelitian yang dilakukan di PAUD Al-Ikhlas Salemba Tengah, Jakarta Pusat pada tahun 2015 dari 8 responden anak-anak menunjukkan peningkatan yang signifikan. Data kuantitatif mengalami peningkatan dalam peningkatan pemahaman bentuk geometri anak pada pra siklus, siklus I dan siklus II. Pada pra siklus, peningkatan pemahaman bentuk geometri sebesar $46 \%$ pada siklus I dengan persentase $61 \%$ dan siklus II dengan persentase $86 \%$.

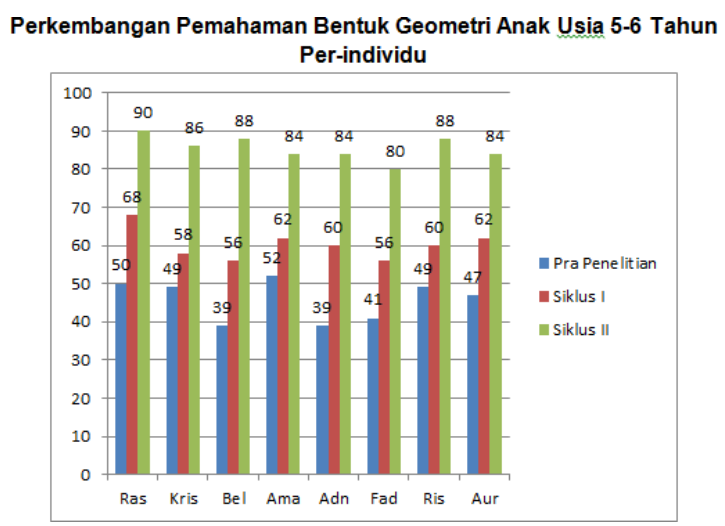

\section{PEMBAHASAN}

Berdasarkan hasil pemberian tindakan dapat disimpulkan bahwa penggunaan kegiatan art and craft dapat meningkatkan pemahaman bentuk geometri anak. Penggunaan kegiatan art and craft diberikan untuk menarik minat anak dalam memahami bentuk geometri melalui kegiatan yang langsung dikerjakan oleh anak. Hal ini dapat membantu anak untuk lebih memahami konsep-konsep geometri melalui kegiatan yang menyenangkan. Selain itu, penggunaan kegiatan art and craft juga melibatkan anak untuk berperan aktif dalam proses kegiatan pembelajaran.

Beberapa aspek yang perlu diperhatikan dan menjadi fokus peningkatan pemahaman bentuk geometri pada anak di antaranya adalah aspek menyimpulkan (inferring), menjelaskan (explaining), menafsirkan (interpreting), membandingkan (comparing), klasifikasi (classifying), 
dan mencontohkan (exemplifying). Konsep pertama yang perlu diajarkan pada anak usia dini sebagai dasar untuk memahami bentuk geometri adalah kesadaran ruang/spasial yang terdapat pada aspek menyimpulkan (inferring). Anak usia dini mulai mempelajari geometri dengan topik topologi, yaitu bagian khusus dari geometri yang menyelidiki tentang hubungan-hubungan. Hubungan yang dimaksudkan adalah hubungan letak atau ruang. Sebelum mengenalkan bentuk geometri guru harus terlebih dahulu mengembangkan kesadaran ruang/spasial pada anak. Selanjutnya anak mulai dikenalkan dengan berbagai bentuk geometri dasar yang berbentuk bangun datar maupun banggun ruang, serta mengenal nama dan ciri dari berbagai bentuk geometri dasar.

Untuk aspek menjelaskan (explaining), sebaiknya guru mengenalkan bentuk-bentuk geometri terlebih dahulu menggunakan media visual maupun konkrit. Anak-anak diajarkan untuk mengenali beberapa jenis bentuk geometris seperti segitiga, persegi, persegi panjang, dan lingkaran. Pembelajaran geometri pada anak usia dini hanya sebatas pada pengenalan bentuk geometri dua dimensi dan tiga dimensi serta sifat geometri serta ciri khusus dari bentuk-bentuk geometri dasar. Sementara itu, pada aspek menafsirkan (interpreting), sebaiknya guru dapat memanfaatkan waktu bermain bebas dengan menyediakan alat permainan yang disesuaikan dengan materi pemahaman bentuk geometri, sehingga anak bisa banyak bereksplorasi dengan berbagai bentuk geometri. Pengalaman tersebut sangat mendukung berkembangnya pemahaman bentuk geometri pada anak. Anak dapat dengan mudah mengenali dan menamai bentuk geometri yang dilihatnya.

Selanjutnya pada aspek membandingkan (comparing), sebaiknya guru mengerti bahwa anak akan memahami konsep melalui pengalaman beraktivitas/bermain dengan benda-benda kongkrit. Oleh karena itu berikan kegiatan bermain dengn benda-benda konkrit di sekitar anak, agar anak mampu menganalisis perbandingan bentuk geometri dan membangun pengetahuannya sendiri, begitu juga pada aspek klasifikasi (classifying), gunakan aktivitas dan kegiatan yang dapat merangsang pemahaman bentuk geometri pada anak. Selain itu berikan contoh-contoh penggunaan bentuk geometri di sekitar lingkungan anak, hal ini dapat mengembangkan aspek mencontohkan (exemplifying) pada anak. Dengan demikian anak mampu menyebutkan bendabenda di sekitar yang menggunakan konsep geometri.

Persiapan yang perlu dilakukan di antaranya adalah perencanaan kegiatan dan pengemasan kegiatan yang disesuaikan dengan cara anak belajar agar anak dapat tetap fokus 
dengan pembelajaran yang diberikan. Kegiatan yang disiapkan guru sebaiknya dapat memenuhi rasa ingin tahu anak dan memberikan kesempatan anak untuk bereksplorasi dengan media yang digunakan, misalnya kegiatan art and craft sebaiknya dikemas dalam suatu kegiatan yang menarik yang dapat membuat anak terlibat aktif dalam kegiatan.

Dalam menggunakan alat dan bahan dalam kegiatan art and craft guru juga harus memperhatikan keamanan untuk anak, misalnya untuk penggunaan gunting dan benda lainnya yang dapat menimbulkan resiko keamanan. Peraturan bersama sebaiknya tetap dibuat agar anak dapat lebih dapat dikondisikan. Anak seringkali belum terlalu memikirkan potensi bahaya yang dapat ditimbulkan dari suatu benda jika tidak digunakan dengan hati-hati atau digunakan untuk sesuatu yang negatif. Oleh karena itu, kecermatan pengawasan perlu dilakukan oleh guru.

Hal lain yang perlu menjadi perhatian guru adalah kesesuaian jumlah alat dan bahan dengan jumlah anak. Jumlah media yang terlalu sedikit sangat beresiko membuat konsentrasi anak pecah dan anak melakukan sesuatu hal di luar kegiatan, sehingga tujuan pembelajaran akan sulit tercapai. Selain itu, pendidik juga tetap perlu memberikan bimbingan secara individu kepada anak karena beberapa anak perlu mendapatkan perhatian secara lebih intensif agar tujuan pembelajaran benar-benar dapat dicapai. Selanjutnya, hal lain yang perlu menjadi perhatian guru adalah sesekali perlu memberikan kesempatan kepada anak untuk melaksanakan kegiatan diluar ruangan agar anak dapat merasakan suasana belajar yang lain, sehingga dapat mendukung keterbukaan pikiran anak.

\section{KESIMPULAN}

Berdasarkan hasil analisis data pada siklus I, diperoleh prosentase sebesar 62\%, dan pada siklus II, diperoleh prosentase keberhasilan sebesar 84\%. Dari data tersebut dapat dikatakan bahwa pemberian tindakan telah memberikan pencapaian keberhasilan yang cukup signifikan dalam mengembangkan pemahaman bentuk geometri anak. Sebagaimana disampaikan pada interpretasi hasil analisis bahwa penelitian ini dikatakan berhasil jika diperoleh keberhasilan mencapai $71 \%$, maka penelitian ini dikatakan berhasil karena prosentase yang dicapai pada siklus II sebesar 84\%. Dengan demikian, maka dapat dinyatakan bahwa kegiatan art and craft dalam pembelajaran konsep bentuk geometri dapat mengembangkan pemahaman bentuk geometri pada anak kelompok B PAUD Al-Ikhlas Salemba Tengah, Jakarta Pusat. Oleh karena itu, pemberian tindakan atau penelitian dihentikan. Berdasarkan hasil analisis data tersebut maka 
peneliti menyimpulkan bahwa kegiatan art and craft dapat digunakan untuk meningkatkan pemahaman bentuk geometri anak usia 5-6 tahun di PAUD Al-Ikhlas, Salemba Tengah, Jakarta Pusat.

\section{DAFTAR PUSTAKA}

Aubrey, Carol. Mathematics Teaching in the Early Years, Britain: The Falmer Press, 1997.

Eliason, Claudia Fuhriman dan Loa Thomshon Jenkins. A Practical Guide to Early Childhood Education Curriculum, United State of Amaerica: Pearson, 2012.

Jackman, Hilda L. Early Education Curriculum, United State of Amerika: Delmar, 2009.

Jannah, Raodatul. Membuat Anak Cinta Matematika dan Eksak Lainnya, Jogjakarta: DIVA Press, 2011.

Kennedy, Tipps Johnson. Guiding Children"s Learning of Mathematics, Unites State of America: Cengage Learning, 2011.

Nograhany Widhi K, Ini Peringkat Kemampuan Matematika Siswa di Dunia, Indonesia Nomor Berapa? http://news.detik.com/read/2013/12/04/144949/2432402/10/ini-peringkatkemampuan-matematika-siswa-di-dunia-indonesia-nomor-berapa diakses pada tanggal 19 Juni 2014

Nusrotul Bariyah, http://nusrotulbariyah.wordpress.com/2010/01/16/geometri/ diakses pada tanggal 24 Maret 2014.

Satria, Mutu Pendidikan di Indonesia Masih Rendah, http://ugm.ac.id/id/post/page?id=4467 diakses pada tanggal 19 Juni 2014

Seefeldt, Carol dan Barbara A.Wasik. Menyiapkan Anak Usia Tiga, Empat, dan Lima Masuk Sekolah Edisi Bahasa Indonesia, Jakarta: Indeks, 2008.

Smith, Susan Sperry. Early Childhood Mathematics Fourth Edition, United State of America: Pearson, 2009.

The National Council of Teachers of Mathematics, Inc. Mathematics for The Young Child, United State of America: Library of Congress Cataloging-in-Publication Data, 1990. 